\title{
Effect of Glucocorticoid Treatment on Biochemical and Hormonal Blood Parameters in Early Pregnant Gilts
}

\author{
By A. Madej ${ }^{1}$, K. Romanowicz ${ }^{4}$, S. Einarsson ${ }^{2}$, M. Forsberg ${ }^{3}$ and B. Barcikowski ${ }^{4}$
}

${ }^{1}$ Department of Animal Physiology, ${ }^{2}$ Department of Obstetrics and Gynaecology and ${ }^{3}$ Department of Clinical Chemistry, Swedish University of Agricultural Sciences, Uppsala, Sweden, and ${ }^{4}$ The Kielanowski Institute of Animal Physiology and Nutrition, Jablonna, Poland.

\begin{abstract}
Madej, A., K. Romanowicz, S. Einarsson, M. Forsberg and B. Barcikowski: Effect of glucocorticoid treatment on biochemical and hormonal blood parameters in early pregnant gilts. Acta vet. scand. 1997, 38, 263-273. - Twenty Polish Landrace gilts were grouped immediately after mating as follows: Experiment I - Group 1 (5 gilts), control animals and Group 2 (5 gilts), injected i.m. with dexamethasone $(30 \mathrm{mg} / \mathrm{kg}$ ) at 12 -h intervals from day 13 to day 22 of pregnancy; Experiment II - Group 3 (5 gilts), injected i.m. with corn oil from day 13 to day 22 of pregnancy and Group 4 (5 gilts), injected i.m. with hydrocortisone acetate $(250 \mathrm{mg})$ at 12 -h intervals from day 11 to day 20 of pregnancy. Gilts were placed in metabolic cages on day 7. On days 34-36 of pregnancy gilts were slaughtered and blood samples were collected. Serum was used for analysis of aspartate aminotransferase (S-ASAT), alanine aminotransferase (S-ALAT), alkaline phosphatase (S-ALP), S-cholesterol, S-triglycerides, S-fructosamine, S-urea, S-total protein, and for electrophoretic fractionation of serum proteins, corticosteroid-binding globulin (CBG), cortisol, progesterone, thyroxine $\left(\mathrm{T}_{4}\right)$ and free $\mathrm{T}_{4}$. There were no significant differences between groups in embryonic survival or in number of viable fetuses after treatment with glucocorticoids. The activity of S-ALP was lower $(\mathrm{p}<0.05)$ in Group 4 than in Group $3(0.5 \mathrm{vs} 1.2 \mu \mathrm{kat} / \mathrm{l})$. Group 4 had higher $(p<0.05)$ levels of S-triglycerides $(1.17$ vs $0.73 \mathrm{mmol} / \mathrm{l})$, S-cholesterol (5.4 vs 2.7 $\mathrm{mmol} / \mathrm{l})$, S-total protein (110.5 vs $93.3 \mathrm{~g} / \mathrm{l})$, S-albumin ( $56.3 \mathrm{vs} 43.3 \mathrm{~g} / \mathrm{l})$ and $\alpha_{2}$-globulin concentrations ( $18.0 \mathrm{vs} 14.3 \mathrm{~g} / \mathrm{l})$ than Group 3 . The hydrocortisone-treated gilts had lower $(\mathrm{p}<0.05)$ CBG $(6.8$ vs $21.3 \mathrm{nmol} / \mathrm{l})$ and $\beta_{1}$ - globulin $(3.25 \mathrm{vs} 5.0 \mathrm{~g} / \mathrm{l})$ concentrations than the oil-treated ones. Concentrations of $\mathrm{T}_{4}$ were lower $(\mathrm{p}<0.05)$ in Groups 2 $(61.3 \mathrm{nmo} / \mathrm{l})$ and $4(49.0 \mathrm{nmol} / \mathrm{l})$ compared with control Groups 1 and $3(88.2$ and 97.0 $\mathrm{nmol} / \mathrm{l}$, respectively). Overall, the treatment of early pregnant gilts with hydrocortisone acetate resulted in decreased levels of S-ALP, CBG, $\beta_{1}$-globulin and $\mathrm{T}_{4}$, and in increased levels of S-cholesterol, S-triglycerides, S-total protein, S-albumin and $\alpha_{2}$-globulin. The only effect of dexamethasone was a lowering of $\mathrm{T}_{4}$. There were no differences in free $T_{4}$, $\mathrm{S}$-fructosamine or S-urea between controls and treatments. Furthermore a negative correlation between triglycerides concentrations and the number of embryos $(r=-0.76$, $\mathrm{p}<0.05$ ) was found in control untreated and oil-treated pregnant gilts.
\end{abstract}

pregnancy; fetus; cholesterol; triglycerioles; enzymes, serum proteins, corticosteroidbinding globulin; thyroxine.

\section{Introduction}

The perception of stress results in the release of corticotropin releasing hormone $(\mathrm{CRH})$ which plays a central role in regulating the release of adrenocorticotropic hormone (ACTH). ACTH acts on the adrenal glands, inducing the secre- 
tion of cortisol. CRH may also act directly or indirectly to enhance cortisol secretion beyond the level achieved through adrenal stimulation by ACTH (Minton \& Parsons 1993). Several studies have demonstrated that plasma cortisol concentration in pigs increase in response to physical and psychological stressors (Klemcke 1994, Wan et al. 1994, Janssens et al. 1995). When infrequent blood sampling is employed, measurement of corticosteroid-binding globulin (CBG) may serve as a more precise measure of a physiological stress response compared with the glucocorticoid concentration (Kattesh et al. 1980). The findings of Behrens et al. (1993) suggest that cortisol may be involved in maternal reproductive failure in the pig. In rats subjected to repeated exposure to stressors and fed a normal laboratory diet, persistently elevated serum concentrations of corticosterone and cholesterol have been observed (Servatius et al. 1994).

The aim of the present work was to study the effect of glucocorticoid treatment on biochemical and hormonal parameters in early pregnant gilts.

\section{Materials and methods}

Twenty Polish Landrace gilts, 9 to 10 months of age and 88 to $119 \mathrm{~kg}$ weight were housed individually at the Kielanowski Institute of Animal Physiology and Nutrition, Jablonna. The barn was illuminated for $12 \mathrm{~h}$ (lights on at $0700 \mathrm{~h}$, lights off at $1900 \mathrm{~h}$ ), and the room temperature varied between 15 and $17^{\circ} \mathrm{C}$. Pigs were fed 2.5 $\mathrm{kg} /$ day of diet containing $12.5 \%$ of crude protein and 11.5 MJ ME/kg. Water was available ad libitum. Experiment I was performed in February/March and Experiment II in March/April 1993.

Animals were grouped immediately after mating as follows: Experiment I - Group 1 (5 gilts), control animals, and Group 2 (5 gilts), injected i.m. with dexamethasone $(30 \mu \mathrm{g} / \mathrm{kg})$ at $12-\mathrm{h}$ intervals from day 13 to day 22 of pregnancy;
Experiment II - Group 3 (5 gilts), injected i.m. with corn oil from day 13 to day 22 of pregnancy and Group 4 (5 gilts), injected i.m. with hydrocortisone acetate $(250 \mathrm{mg})$ at 12 -h intervals from day 11 to day 20 of pregnancy. On days 34-36 of pregnancy, all gilts were slaughtered, and blood samples were collected. The ovaries and uteri were weighed and dissected in order to count numbers of corpora lutea and fetuses, respectively. The adrenal glands were also collected.

Blood serum was used for the analysis of aspartate aminotransferase (S-ASAT) and alanine aminotransferase (S-ALAT) as recommended by the Scandinavian Committee on Enzymes (1974). The inter-assay coefficient of variation was $3.1 \%$ and $2.7 \%$, respectively.

Serum alkaline phosphatase (S-ALP) activities were determined as recommended by the German Society for Clinical Chemistry (Hafkenschied \& Kohler 1986). The inter-assay coefficient of variation was $3.7 \%$.

Serum concentrations of triglycerides (S-triglycerides), cholesterol (S-cholesterol), fructosamine (S-fructosamine), urea (S-urea) and total protein (S-protein) were determined by using standardized reagents kits from Roche, Basel, Switzerland.

All of the above-mentioned analysis were performed in a computerized multichannel spectrophotometer (Cobas Mira, Roche, Basel, Switzerland).

The electrophoretic separation of proteins in porcine serum was performed by means of the Paragon Serum Protein Electrophoresis (Beckman Instruments AB, Bromma, Sweden). The electrophoretic pattern was resolved into albumin, $\alpha_{1}$-globulin, $\alpha_{2}$-globulin, $\beta_{1}$-globulin, $\beta_{2}$ globulin and $\gamma$-globulin fractions. The percentage and the mean concentration of each fraction based on the total protein concentration were calculated using software from Pharmacia AB (Uppsala, Sweden). 
The binding capacity of corticosteroid-binding globulin (CBG) was estimated as a 1-point assay and included the addition of cortisol to saturation according to Nyberg et al. (1988).

Serum concentrations of cortisol were determined by using an enhanced chemiluminescence immunoassay (Amerlite, Kodak Clinical Diagnostics Ltd, Amersham, England) according to a method previously described (Magnusson et al. 1994). The intra-assay coefficient of variation was below $9.8 \%$ for concentrations of cortisol between 11.6 and $1125.0 \mathrm{nmol} / \mathrm{l}$.

Progesterone concentrations were determined using an enhanced chemiluminescence immunoassay with modifications as described by Rojkittikhun et al. (1993). The intra-assay coefficient of variation was below $2.1 \%$ for concentrations of progesterone between 2.0 and 160 $\mathrm{nmol} / \mathrm{l}$.

Thyroxine $\left(\mathrm{T}_{4}\right)$, and free $\mathrm{T}_{4}$ were quantified using an enhanced chemiluminescence immunoassay (Amerlite, Kodak Clinical Diagnostics Ltd, Amersham, England) according to the manufacturer's instructions. Serial dilution of porcine plasma produced inhibition curves parallel to the standard curve of $\mathrm{T}_{4}$. The sensitivity of $\mathrm{T}_{4}$ assay was $4.2 \mathrm{nmol} / \mathrm{l}$. The inter-assay coefficient of variation for quality control sample was $2.3 \%($ mean $=52.8 \mathrm{nmol} / \mathrm{l}, \mathrm{n}=3)$. The corresponding intra-assay coefficient of variation was below $5 \%$ for concentrations of $\mathrm{T}_{4}$ up to $320 \mathrm{nmo} / \mathrm{l}$.

The analysis of all samples for each parameter was performed in duplicate in a single assay. All parameters were computed and analysed for treatment effects within experiments using the analysis of variance and Duncan multiple-range test in the Statistical Analysis System (SAS Institute, Inc., 1987) program package. Means are expressed as \pm s.e.m.

\section{Results}

Pregnancy was confirmed in 5 gilts from Group 1,4 gilts in Group 2, 3 gilts in Group 3 and 4 gilts in Group 4. There were no significant differences between groups in embryonic survival or in number of viable fetuses after treatment with glucocorticoids. Percentages of corpora lutea represented by viable fetuses were $94 \pm$ $15 \%, 96 \pm 3 \%, 82 \pm 20 \%$ and $79 \pm 18 \%$ in control, dexamethasone-, oil- and hydrocortisonetreated gilts, respectively (Table 1).

The activity of S-ALP (Fig. 1) was lower $(\mathrm{p}<0.05)$ in gilts treated with hydrocortisone (Group 4) than in oil-treated animals (Group 3) $(0.5 \pm 0.1$ vs $1.2 \pm 0.4 \mu \mathrm{kat} / \mathrm{l})$. Neither S-ASAT nor S-ALAT were affected by any of the treatments. Gilts belonging to Group 4 appeared to have higher $(\mathrm{p}<0.05)$ S-triglycerides $(1.17 \pm 0.1$

Table 1. Number of corpora lutea, percentage corpora lutea represented by a viable fetus and number of viable fetuses on days 34-36 of pregnancy in gilts.

\begin{tabular}{lcccc}
\hline & $\begin{array}{c}\text { Group 1 } \\
\text { Control } \\
(\mathrm{n}=5)\end{array}$ & $\begin{array}{c}\text { Group 2 } \\
\text { Dexamethasone } \\
(\mathrm{n}=4)\end{array}$ & $\begin{array}{c}\text { Group 3 } \\
\text { Oil } \\
(\mathrm{n}=3)\end{array}$ & $\begin{array}{c}\text { Group 4 } \\
\text { Hydrocortisone } \\
(\mathrm{n}=4)\end{array}$ \\
\hline $\begin{array}{l}\text { No. of corpora lutea } \\
\begin{array}{l}\text { \% corpora lutea } \\
\text { represented by a viable } \\
\text { fetus on days 34-36 }\end{array}\end{array}$ & $15.0 \pm 1.7$ & $10.8 \pm 0.9$ & $13.0 \pm 1.0$ & $11.5 \pm 0.5$ \\
$\begin{array}{l}\text { No. of viable fetuses on } \\
\text { days 34-36 }\end{array}$ & $94.0 \pm 15.0$ & $95.6 \pm 2.6$ & $81.6 \pm 19.9$ & $79.2 \pm 18.2$ \\
\hline
\end{tabular}




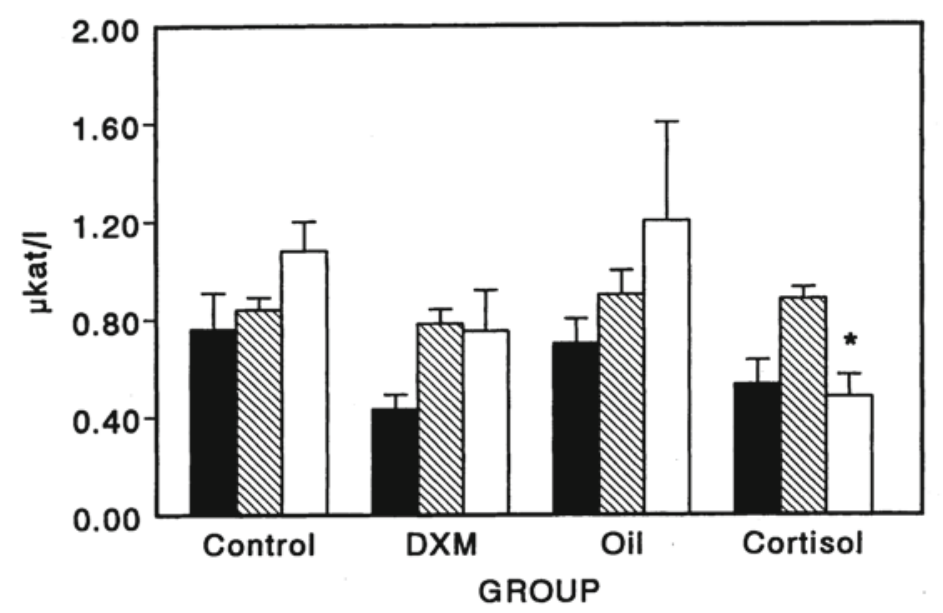

Figure 1. Mean \pm s.e.m. of S-ASAT ( $\mu \mathrm{kat} / \mathrm{l}$; closed bars), S-ALAT ( $\mu \mathrm{kat} / \mathrm{l}$; hatched bars) and S-ALP ( $\mu \mathrm{kat} / \mathrm{l}$; open bars) in control untreated (Control), dexamethasone-treated (DXM), oil-treated (Oil) and hydrocortisonetreated (Cortisol) early pregnant gilts. ${ }^{*}$ denotes values that are significantly different $(p<0.05)$ from those for corresponding control animals.

vs $0.73 \pm 0.1 \mathrm{mmol} / \mathrm{l})$ and S-cholesterol concentrations $(5.4 \pm 0.4$ vs $2.7 \pm 0.3 \mathrm{mmol} / \mathrm{l})$ than Group 3 gilts (Fig. 2). S-total protein (110.5 \pm $3.1 \mathrm{vs} 93.3 \pm 0.7 \mathrm{~g} / \mathrm{l})$ and S-albumin $(56.3 \pm 1.8$ vs $43.3 \pm 0.9 \mathrm{~g} / \mathrm{l})$ were higher in Group 4 gilts than in Group 3 gilts (Fig. 3). Treatment with hydrocortisone resulted in a significant reduction of CBG binding capacity $(6.8 \pm 2.1$ vs 21.3 $\pm 4.8 \mathrm{nmol} / \mathrm{l})$ as well as in $\beta_{1}$-globulin concentrations $(3.25 \pm 0.3$ vs $5.0 \pm 1.0 \mathrm{~g} / \mathrm{l})$ compared

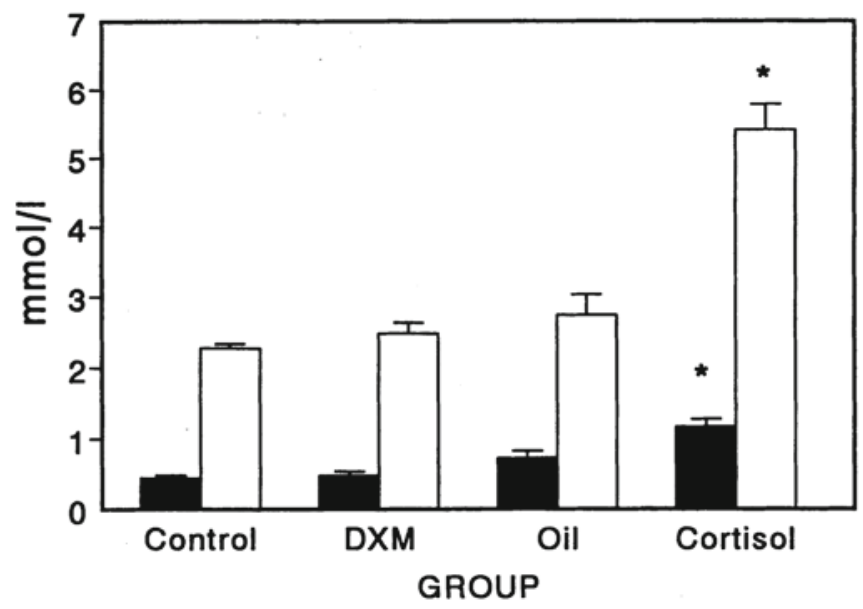

Figure 2. Mean \pm s.e.m. of S-triglycerides ( $\mathrm{mmol} / \mathrm{l}$; closed bars) and S-cholesterol (mmol/l; open bars) in control untreated (Control), dexamethasone-treated (DXM), oil-treated (Oil) and hydrocortisone-treated (Cortisol) early pregnant gilts. ${ }^{*}$ denotes values that are significantly different $(\mathrm{p}<0.05)$ from those for corresponding control animals. 


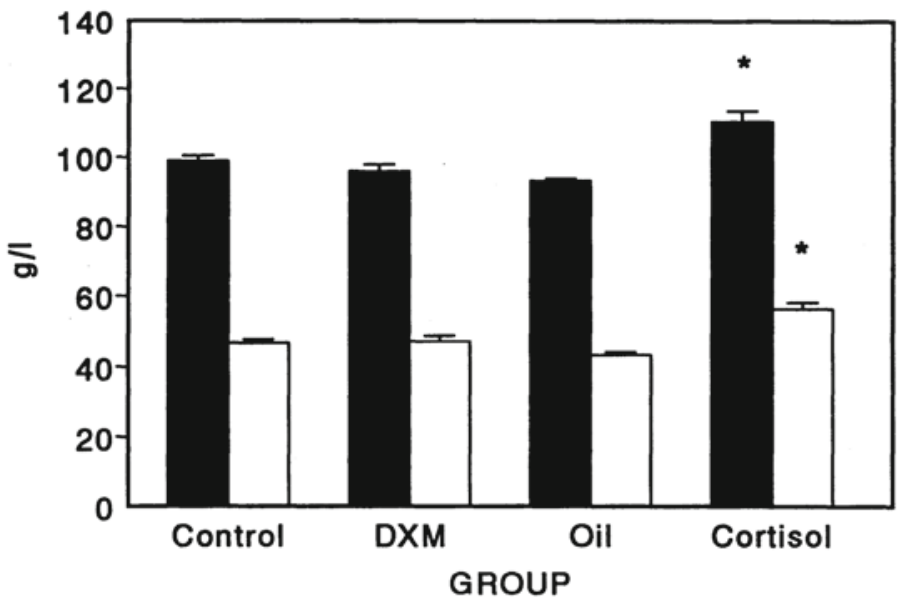

Figure 3. Mean \pm s.e.m. of S-protein ( $\mathrm{g} / \mathrm{l}$; closed bars) and S-albumin $(\mathrm{g} / \mathrm{l}$; open bars) in control untreated (Control), dexamethasone-treated (DXM), oil-treated (Oil) and hydrocortisone-treated (Cortisol) early pregnant gilts. ${ }^{*}$ denotes values that are significantly different $(\mathrm{p}<0.05)$ from those for corresponding control animals.

with the oil treatment, respectively (Fig. 4). Fig. 4 also depicts concentrations of $\alpha_{2}$-globulin which increased in hydrocortisone-treated gilts when compared with oil-treated animals (18.0 \pm 0.7 vs $14.3 \pm 0.7 \mathrm{~g} / \mathrm{l})$. There were no differ- ences in serum progesterone or cortisol concentrations between groups in this study (Fig. 5). In both dexamethasone- and hydrocortisonetreated gilts the weights of the adrenal glands were significantly lower $(p<0.05)$ than in con-

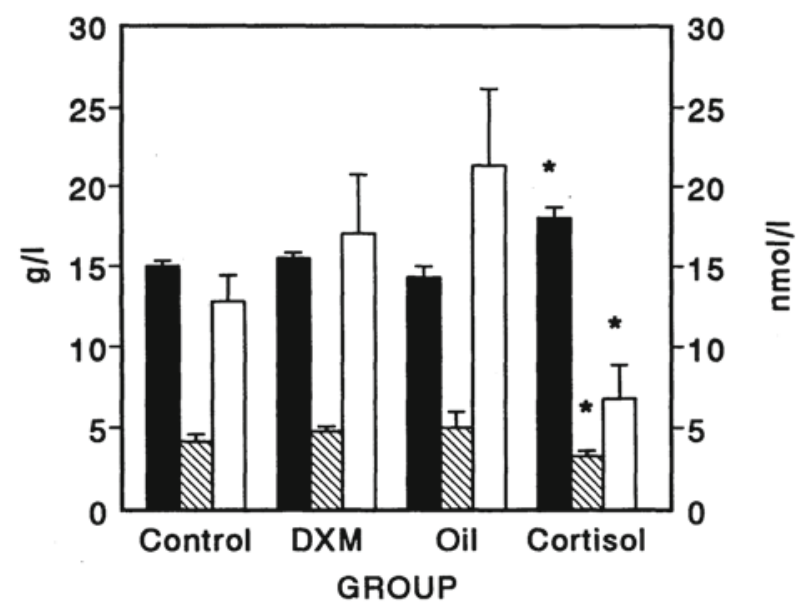

Figure 4. Mean \pm s.e.m. of $\alpha_{2}$-globulin (g/l; closed bars), $\beta_{1}$-globulin ( $\mathrm{g} / \mathrm{l}$; hatched bars) and CBG (nmol/l; open bars) in control untreated (Control), dexamethasone-treated (DXM), oil-treated (Oil) and hydrocortisonetreated (Cortisol) early pregnant gilts. ${ }^{*}$ denotes values that are significantly different $(p<0.05)$ from those for corresponding control animals. 


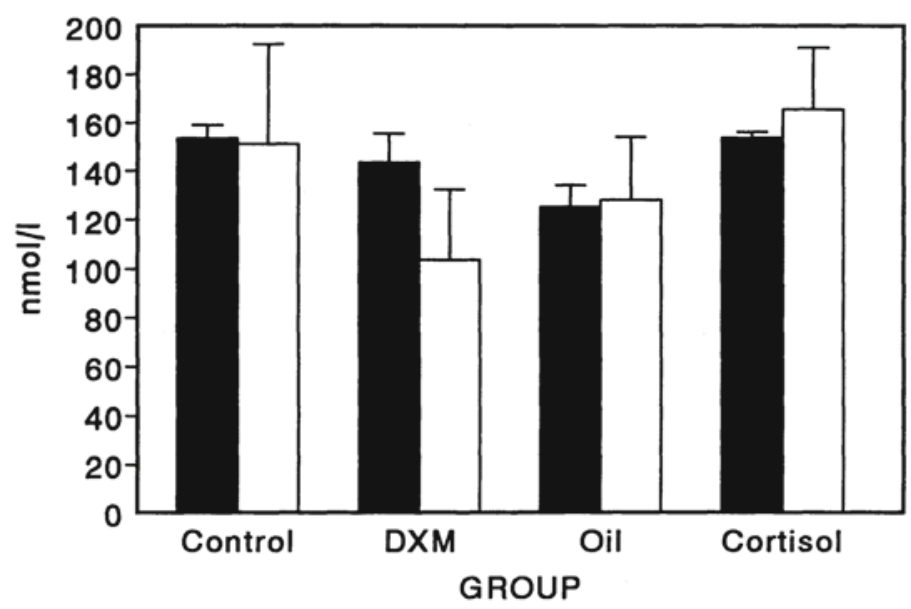

Figure 5. Mean \pm s.e.m. of progesterone (nmol/l; closed bars) and cortisol ( $\mathrm{nmol} / \mathrm{l}$; open bars) in control untreated (Control), dexamethasone-treated (DXM), oil-treated (Oil) and hydrocortisone-treated (Cortisol) early pregnant gilts. * denotes values that are significantly different $(\mathrm{p}<0.05)$ from those for corresponding control animals.

trols 1 and $3(4.5 \pm 0.5$ vs $6.0 \pm 0.3 \mathrm{~g}$ and $3.7 \pm$ 0.1 vs $5.8 \pm 0.8 \mathrm{~g}$, respectively). As shown in Fig. 6, concentrations of $\mathrm{T}_{4}$ were lower $(\mathrm{p}<0.05)$ in dexamethasone-treated $(61.3 \pm 1.9 \mathrm{nmo} / \mathrm{l})$ and hydrocortisone-treated gilts $(49.0 \pm 3.4$ $\mathrm{nmol} / \mathrm{l}$ ) compared with respective control groups 1 and $3(88.2 \pm 10.0$ and $97.0 \pm 11.5$ $\mathrm{nmol} / \mathrm{l})$. There were no differences in free $\mathrm{T}_{4}$, S-fructosamine or S-urea between treatments. S-cholesterol was correlated negatively with SALP and free $\mathrm{T}_{4}$, and positively with S-triglyce-

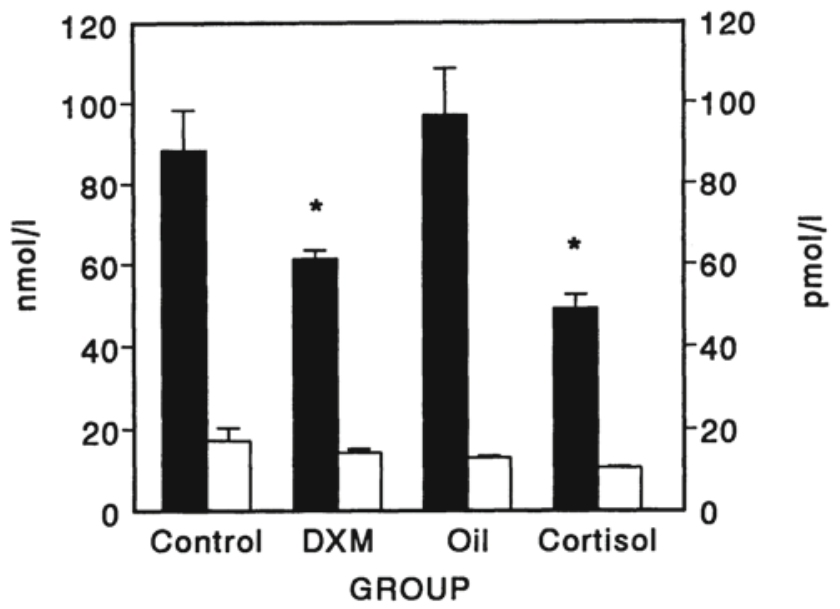

Figure 6. Mean \pm s.e.m. of $\mathrm{T}_{4}$ (nmol/l; closed bars) and free $\mathrm{T}_{4}$ (pmol/l; open bars) in control untreated (Control), dexamethasone-treated (DXM), oil-treated (Oil) and hydrocortisone-treated (Cortisol) early pregnant gilts. $*$ denotes values that are significantly different $(\mathrm{p}<0.05)$ from those for corresponding control animals. 
rides, S-protein and $\alpha_{2}$-globulin (Spearman rank correlation varied between 0.53 and 0.86 , $\mathrm{p}<0.05$ ). CBG was correlated positively with S-ALP and negatively with S-protein and $\alpha_{2}$-globulin (Spearman rank correlation varied between 0.51 and $0.63, \mathrm{p}<0.05$ ). Overall, the treatment of early pregnant gilts with hydrocortisone acetate resulted in decreases in S-ALP, CBG, $\beta_{1}$-globulin and $T_{4}$, and increases in S-cholesterol, S-triglycerides, S-total protein, $\mathrm{S}$-albumin and $\alpha_{2}$-globulin. The only effect that dexamethasone had was to lower of $\mathrm{T}_{4}$.

Furthermore a negative correlation between triglycerides concentrations and the number of embryos $(r=-0.76, p<0.05)$ was found in control untreated and oil-treated pregnant gilts.

\section{Discussion}

Stress can be defined as any stimulus, physical or emotional, that disturbs the homeostasis of the organism. Here, we studied the effects of repeated injections of dexamethasone, corn oil or hydrocortisone acetate on certain blood constituents during early pregnancy in gilts. Alkaline phosphatases are a family of cell-surface glycoproteins expressed in a variety of tissues. Work by Johansson et al. (1993) supported the hypothesis that in the mouse ALP may be involved in the exchange of substances between the fetal and maternal circulation in the mature placenta. It was also found that serum ALP increases in normal pregnancy in women (Okesina et al. 1995). In the present study a reduction of S-ALP activity following the treatment with hydrocortisone was seen in pregnant gilts. Previously, Kirchgessner et al. (1987) reported that S-ALP activity was reduced in fattening pigs given feed lacking trace elements or vitamins compared with control animals. Additionally, Madej et al. (1992) found that pregnant mink fed polychlorinated biphenyls (PCB) did not deliver any offspring and had lower S-ALP levels compared with control animals. It is reasonable to conclude that the function of ALP in pregnant pigs needs to be further studied.

A reduction in plasma CBG binding capacity after chronic exposure to various environmental or management-related stressors has been reported in the pig (Kattesh et al. 1980, Barnett et al. 1985). Behrens et al. (1993) reported that pseudopregnant gilts that received $600 \mathrm{mg}$ hydrocortisone acetate twice daily during 10 days had a 5.2 fold lower CBG concentration compared with control gilts. Although the total plasma concentration of cortisol was significantly elevated following repeated administration of hydrocortisone, the plasma distribution of cortisol between protein-bound and unbound forms was not altered. A reduction in CBG synthesis, corresponding to increasing corticosteroid levels, would effectively increase the clearance rate and thus lowering circulating corticosteroid concentrations. According to Behrens et al. (1993) this may serve as a physiological means of adaptation to a stress for the animal. In the present study, ten days after the last injection, the hydrocortisone-treated gilts appeared to have a 3.1 fold lower CBG-binding capacity compared with control gilts. This decrease in CBG was not associated with a significant change in the total serum concentration of cortisol or progesterone. The dose of hydrocortisone acetate used in our study was similar to that used by Barb et al. (1982) who reported a 3 -fold elevation in plasma cortisol levels in gilts during a twice-daily injection of $250 \mathrm{mg}$ hydrocortisone acetate for the first 12 days of the oestrous cycle. It is interesting to note that a steady decline in CBG-binding capacity occurs in untreated pregnant sows (Tsuma et al. 1996). Thus, the biological significance of $\mathrm{CBG}$ changes is not clear and requires further investigation.

CBG-binding capacity was not depressed in our dexamethasone-treated gilts. It might, there- 
fore, be presumed that either the dose of dexamethasone was too low or that it had no effect owing to the fact that $\mathrm{CBG}$ exhibits less than $0.1 \%$ binding affinity for dexamethasone compared with cortisol (Pugeat et al. 1981).

The decrease in $\mathrm{T}_{4}$ concentrations after treatment with dexamethasone or hydrocortisone agrees the findings of Baldi et al. (1994). These investigators reported that treatment of pigs with clenbuterol for 40 days resulted in a lowering of $\mathrm{T}_{4}$, but there were no effects on cortisol or glucose concentrations. In another study (Servatius et al. 1994), corticosterone-treated rats exhibited elevated corticosterone levels on the 8th experimental day, accompanied by elevated cholesterol levels and suppressed $\mathrm{T}_{4}$ levels. However, elevated cholesterol levels were also found in adrenalectomized rats and these elevations were accompanied by suppressed triiodothyronine levels. They concluded that persistent corticosterone elevations are not necessary for plasma cholesterol to remain elevated after stressor exposure, but further research is necessary to clarify the role of the hypothalamic-pituitary-adrenal and thyroid axes in stress-induced plasma cholesterol elevations. The increase in triglycerides and cholesterol concentrations seen concomitant with a decrease in $\mathrm{T}_{4}$ concentrations after treatment with hydrocortisone in the present study suggests that there are some similarities in the response to chronic stress between pigs and rats.

The findings of Wise et al. (1993) provide substantial evidence that pigs selected for high cholesterol concentrations had a lower ovulation rate, smaller litter size and heavier adrenal glands compared with pigs selected for low cholesterol concentrations. It is interesting to note that adrenal weights were increased in the high cholesterol line and decreased in the low cholesterol line. In the present study the treatment with hydrocortisone resulted in decreased adrenal weights concomitantly with increase in cholesterol and triglycerides concentrations. However, the decrease in adrenal weights after dexamethasone treatment was not related to cholesterol or triglycerides changes. When only the control animals were considered a negative correlation between the number of viable fetuses and triglycerides concentrations was found here which is in agreement with the above-mentioned findings of Wise et al. (1993). It was previously suggested that an increase in liver and serum cholesterol due to PCB intake in rats could be mediated through the stimulation of hepatic cholesterogenesis and might in part be related to the enhanced synthesis of corticosterone under stressful conditions (Kato et al. 1982). Furthermore, Quazi et al. (1983) concluded that the elevation in serum albumin and protein seen in the PCB-treated rats may be due to the increase in liver microsomal protein synthesis. The increases in $\alpha_{2}$-globulin and S-protein concentrations found in pigs in the present study correspond with observations made in dogs given prednisone (Harvey \& West 1987). An acute inflammation induced in pigs resulted in a 15 -fold increase of $\alpha_{2}$-globulin concentration (Lampreave et al. 1994). These authors concluded that $\alpha_{2}$-globulin could be a major acute-phase protein in the pig and named it pigMAP. It should be noted that in our hydrocortisone-treated gilts the concentration of $\alpha_{2}$-globulin increased an average of only $25 \%$. Hence, even a small elevation in $\alpha_{2}$-globulin concentrations could indicate an alteration in homeostatic mechanisms in response to stress in pregnant pigs.

Larsson et al. (1985) found that in pigs, thyroxine-binding globulin (TBG) had electrophoretic mobility in the $\alpha_{2}$-globulin region and thyroxin-binding prealbumin (TBPA) in the $\beta$-globulins region. Thus, this may explain the decrease in both $\beta_{1}$-globulin and $\mathrm{T}_{4}$ concentrations after hydrocortisone treatment found in the present study. 
In dogs, serum fructosamine reflects the average blood glucose concentration over the previous 1-3 weeks and is a reliable screening test for Diabetes mellitus (Jensen 1994). According to Jensen (1994) hyperglycaemic non-diabetic dogs may have normal serum fructosamine concentrations. To our knowledge, there is no information concerning fructosamine concentrations in early pregnant pigs. We could not find any change in fructosamine concentrations after treatment with glucocorticoids. Moore \& Hoenig (1993) reported that insulin and glucose concentrations, or glucose tolerance, in dogs were not altered by the oral administration for 4 weeks of an anti-inflammatory doses of prednisone.

In pigs, a decrease in urea concentration is suggestive of enhanced nitrogen retention (Baldi et al. 1994). These authors also concluded that increased urea concentrations after the acute stress response are probably due to increased protein catabolism associated with muscle damage. In the present study, neither dexamethasone nor hydrocortisone affected the serum urea concentration.

In conclusion, the treatment of early pregnant gilts with hydrocortisone acetate resulted in decreases of S-ALP, CBG, $\beta_{1}$-globulin and $\mathrm{T}_{4}$, and increases in S-cholesterol, S-triglycerides, S-total protein, S-albumin and $\alpha_{2}$-globulin. The only effect that dexamethasone had was to lower $T_{4}$. Neither embryonic survival nor the number of viable fetuses were affected by the treatment applied. Nevertheless, those blood constituents which were affected by glucocorticoids could be used as biomarkers of a stress response in pregnant pigs.

\section{Acknowledgements}

This study was supported by the Swedish Council for Forestry and Agricultural Research.

\section{References}

Anonymous: Scandinavian Committee on Enzymes: Recommended methods for determining of four enzymes in blood. Scand. J. Clin. Lab. Invest., 1974, 33, 291-306.

Baldi A, Bontempo V, Cheli F, Corino C, Polidori F: Hormonal and metabolic responses to the stress of transport and slaughterhouse procedures in clenbuterol-fed pigs. J. vet. Med. A, 1994, 41, 189-196.

Barb CR, Kraeling RR, Rampacek GB, Fonda ES, Kiser TE: Inhibition of ovulation and LH secretion in the gilt after treatment with ACTH or hydrocortisone. J. Reprod. Fert., 1982, 64, 85-92.

Barnett JL, Winfield CG, Cronin GM, Hemsworth PH, Dewar AM: The effect of individual and group housing on behavioural and physiological responses related to the welfare of pregnant pigs. Appl. Anim. Behav. Sci., 1985, 14, 149-161.

Behrens MJ, Kattesh HG, Baumbach GA: Plasma and uterine cortisol, progesterone and protein changes in pseudopregnant gilts treated with hydrocortisone acetate. Theriogenology 1993, 40, 1231-1241.

Hafkenschied JCM, Kohler BEM: Temperature-convertion factors for four enzymes in commercial control sera. Clin. Chem., 1986, 1616.

Harvey JW, West CL: Prednisone-induced increases in serum alpha-2-globulin and haptoglobin concentrations in dogs. Vet. Pathol., 1987, 24, 90-92.

Janssens CJJG, Helmond FA, Wiegant VM: The effect of chronic stress on plasma cortisol concentrations in cyclic female pigs depends on the time of day. Dom. Anim. Endocrinol., 1995, 12, 167177.

Jensen $A L$ : Serum fructosamine as a screening test for diabetes mellitus in non-healthy middle-aged to older dogs. J. vet. Med. A. 1994, 480-484.

Johansson S, Wide M, Young E, Lindblad P: Expression of alkaline phosphatase in the mature mouse placenta visualized by in situ hybridization and enzyme histochemistry. Anat. Embryol., 1993, 187, 409-414.

Kato N, Mochizuki S, Kawai K, Yoshida A: Effect of dietary levels of sulfur-containing acids on liver drug-metabolizing enzymes, serum cholesterol and urinary ascorbic acid in rats fed PCB. J. Nutr., 1982, 112, 848-854.

Kattesh HG, Kornegay ET, Knight JW, Gwazdaukas $F G$, Thomas HR, Notter DR: Glucocorticoid concentrations, corticosteroid binding protein characteristics and reproductive performance of sows 
and gilts subjected to applied stress during midgestation. J. Anim. Sci., 1980, 50, 897-905.

Kirchgessner M, Roth FX, Roth HP: Effects of a grain-rich diet without added trace elements and vitamins on various performance values in fattening pigs. Zentralbl. Veterinarmed. A, 1987, 34, 188-203.

Klemcke HG: Responses of the porcine pituitary-adrenal axis to chronic intermittent stressor. Dom. Anim. Endocrinol. 1994, 11, 133-149.

Lampreave F, González-Ramón N, Martínez-Ayensa $S$, Hernandez MA, Lorenzo HK, Garcia-Gil A, Piñeiro A: Characterization of the acute phase serum protein response in pigs. Electrophoresis 1994, 15, 672-676.

Larsson M, Pettersson T, Calström A: Thyroid hormone binding in serum of 15 vertebrate species: Isolation of thyroxine-binding globulin and prealbumin analogs. Gen. Comp. Endocrinol., 1985, $58,360-375$.

Madej A, Forsberg $M$, Edqvist L-E: Urinary excretion of cortisol and oestrone sulphate in pregnant mink fed by PCB and fractions of PCB. AMBIO, 1992, 21, 582-585.

Magnusson U, Holst H, Kindahl H, Karlsson A: Effect of mimicking prepartum concentration of estradiol- $17 \beta$ on the inflammatory response to endotoxin in gilts. Am. J. Vet. Res., 1994, 55, 785-789.

Minton JE, Parsons KM: Adrenocorticotropic hormone and cortisol response to corticotropin-releasing factor and lysine vasopressin in pigs. J. Anim. Sci., 1993, 71, 724-729.

Moore GE, Hoenig M: Effects of orally administered prednisone on glucose tolerance and insulin secretion in clinically normal dogs. Am. J. Vet. Res., 1993, 54, 126-129.

Nyberg L, Lundström K, Edfors-Lilja I, Rundgren M: Effects of transport stress on concentrations of cortisol, corticosteroid-binding globulin and glucocorticoid receptors in pigs with different halothane genotypes. J. Anim. Sci., 1988, 66, 12011211.

Okesina AB, Donaldson D, Lascelles PT, Morris P: Effect of gestational age on levels of serum alkaline phosphatase isoenzymes in healthy pregnant women. Int. J. Gynaecol. Obstet., 1995, 48, 25-29.

Pugeat MM, Dunn JF, Nisula BC: Transport of steroid hormones: interaction of 70 drugs with testosterone-binding globulin and corticosteroidbinding globulin in human plasma. J. Clin. Endocrinol. Metab., 1981, 53, 69-75.
Quazi S, Yokogoshi H, Yoshida A: Effect of dietary fiber on hypercholesterolemia induced by dietary PCB or cholesterol in rats. J. Nutr., 1983, 113, 1109-1118.

Rojkittikhun T, Einarsson S, Zilinskas $H$, Edqvist $L-E$, Uvnäs-Moberg $K$, Lundeheim $N$ : Effect of insulin administration at weaning on hormonal patterns and reproductive performance in primiparous sows. J. vet. Med. A, 1993, 40, 161-168.

Servatius RJ, Ottenweller JE, Natelson BH: A comparison of the effects of repeated stressor exposures and corticosterone injections on plasma cholesterol, thyroid hormones and corticosterone levels in rats. Life Sci., 1994, 55, 1611-1617.

SAS Institute, Inc.: SAS/STAT ${ }^{\circledR}$ Guide for Personal Computers, Version 6 Edition. SAS Institute, Inc., Cary, NC, 1987.

Tsuma VT, Einarsson S, Madej A, Kindahl H, Lundeheim $N$ : Effect of food deprivation during early pregnancy on endocrine changes in primiparous sows. Anim. Reprod. Sci., 1996, 41, 267-278.

Wan SS, Hennessy DP, Cranwell PD: Seasonal infertility, stress and adrenocortical responsiveness in pigs. Anim. Reprod. Sci., 1994, 34, 265-279.

Wise T, Young LD, Pond WG: Reproductive, endocrine, and organ weight differences of swine selected for high or low serum cholesterol. J. Anim. Sci., 1993, 71, 2732-2738.

\section{Sammanfattning}

Effekt av glukokortikoidbehandling på biokemiska och hormonella parametrar hos tidigt dräktiga gyltor.

Studien omfattade 20 polska Lantrasgyltor, som uppstallades vid The Kielanowski Institute of Animal Physiology and Nutrition, Jablonna, Polen. Efter betäckning placerades gyltorna i metabolimsburar. Vi behandlade gyltorna med upprepade doser av dexametason, vegetabilisk olja respektive hydrokortison från dag 11-13 t.o.m. dag 20-22 efter betäckning. Dessutom hade vi en kontrollgrupp utan någon behandling. I samband med avlivningen (dag 34-36 efter betäckning) utfördes morfologiska undersökningar av äggstockarna, livmoder, binjurarna och fostren och dessutom togs blodprov för klinisk kemiska analyser. De serumanalyser som utfördes var alaninaminotransferas (S-ALAT), alkaliskt fosfatas (S-ALP), aspartataminotransferas (S-ASAT), S-kolesterol, S-triglycerider, S-fruktosamin, S-urea, 
S-totalproteiner, elektroforetisk separation av serumproteiner, kortikosteroid-bindande globulin (CBG), kortisol, progesteron, thyroxin $\left(\mathrm{T}_{4}\right)$ och fritt $\mathrm{T}_{4}$. Förändringarna i koncentrationer av blodparametrarna efter behandlingen med glukokortikoider ledde inte till minskat antal foster $\mathrm{i}$ förhållande till antalet gulkroppar. Behandlingen av dräktiga gyltor med hydrokortison resulterade i ökade koncentrationer av S-triglycerider (1,17 vs $0,73 \mathrm{mmol} / \mathrm{l})$, S-kolesterol $(5,4$ vs $2,7 \mathrm{mmol} / \mathrm{l})$, S-totalproteiner (110,5 vs 93,3 g/1), S-albumin (56,3 vs 43,3 g/1) samt $\alpha_{2}$-globulin (18,0 vs 14,3 g/l) jämfört med kontroll- gruppen. Samtidigt sågs en sänkning av S-ALP $(0,5$ resp $1,2 \mu \mathrm{kat} / \mathrm{l}), \mathrm{T}_{4}(49,0 \mathrm{resp} 97,0 \mathrm{nmol} / \mathrm{l}), \beta_{1}$-globulin $(3,25$ resp $5,0 \mathrm{~g} / \mathrm{l})$ och CBG $(6,8 \mathrm{resp} 21,3 \mathrm{nmol} / 1)$ jämfört med kontrollgruppen. Tillförsel av dexametason påverkade endast koncentrationen av $\mathrm{T}_{4}$ vilken var lägre än i kontrollgruppen (61,3 resp 88,2 nmo/1). När vi försökte att relatera antalet foster till koncentrationerna av analyserade serumparametrar hos kontrollgrupperna, fann vi en negativ korrelation mellan antalet foster och koncentrationerna av S-triglycerider, dvs. ju högre koncentration av S-triglycerider desto lägre antal foster.

(Received November 13, 1996; accepted May 6, 1997).

Reprints may be obtained from: A. Madej, Department of Animal Physiology, Swedish University of Agricultural Sciences, P.O. Box 7045, S-75007 Uppsala, Sweden. E-mail: Andrzej.Madej@djfys.slu.se, fax: +46 (0) 18-672852, tel: +46 (0) 18-672114. 